\title{
Productivity and water use of lucerne and two lucerne-grass mixtures in Canterbury
}

B.A. MCKENZIE, P. GYAMTSHO and R J. LUCAS Plant Science Department, Lincoln University, Canterbury

\begin{abstract}
The long term trial, on a Templeton fine sandy loam, is a factorial combination of 3 pasture swards (pure WL320 lucerne, lucerne-'Grasslands Matua' prairie grass and lucerne- 'Grasslands Maru' phalaris) and 2 grazing durations (long and short). The 0.04-ha plots were sown in November 1986 with lucerne drilled across the grass rows. For the water use study, in 1988-89, $8 \mathrm{~m}^{2}$ mini plots of pure lucerne, lucerne-phalaris, and lucerne-prairie in deep or shallow soil were selected. Pure lucerne plots produced annual dry matter (DM) yields of $12700 \mathrm{~kg} / \mathrm{ha}$, lucerne-phalaris 11600 and lucerne-prairie 10400. Deep soils had higher production $(12600 \mathrm{~kg} / \mathrm{ha})$ than did shallow soils $(10900 \mathrm{~kg} / \mathrm{ha})$. The lucerne-phalaris mixture had about $75-95 \%$ lucerne, while lucerne in the lucerne-prairie mixture ranged from $25 \%$ in winter to $65 \%$ in summer. The lucerne-prairie plots with deep soils had at least $60 \%$ lucerne while shallow soils had as little as $25 \%$. Mean water use efficiency (WUE) was 25, 22 and 20 $\mathrm{kg} \mathrm{DM} / \mathrm{ha} / \mathrm{mm}$ for pure lucerne, lucernephalaris and lucetne-prairie, respectively. Shallow soils had WUE of $21 \mathrm{~kg} \mathrm{DM} / \mathrm{ha} / \mathrm{mm}$ $\mathrm{H}_{2} \mathrm{O}$ and deep soils $24 \mathrm{~kg} \mathrm{DM} / \mathrm{ha} / \mathrm{mm}$. Soil water extraction 'patterns differed little in shallow soils, but in deep soils pure lucerne extracted water to at least $100 \mathrm{~cm}$ while lucernephalaris and lucerne-prairie extracted soil moisture down to about $80 \mathrm{~cm}$. Lucerne and phalaris roots were both found down to $90 \mathrm{~cm}$ and from $\mathrm{O}-20 \mathrm{~cm}$ most of the root mass was lucerne. With the lucerne-prairie mixture from O-20 cm, root mass was about $50 \%$ for each species and lucerne root mass was significantly reduced below $50 \mathrm{~cm}$.
\end{abstract}

Keywords lucerne, alfalfa, prairie grass, lucerne-grass mixtures, water use, yield, roots, Medicago saliva, Bromus willdenowii, Phalaris aquatica

\section{Introduction}

Canterbury has approximately 300,000 ha of shallow drought-prone soils, where lucerne (Medicago sativa L.) can provide higher dry matter (DM) production than ryegrass-white clover pastures. Also lucerne is resistant to grass grub and produces high quality feed.

However, lucerne productivity in winter and early spring is lower than that of grass-clover, which restricts the proportion of a farm which may be planted in lucerne because of high animal feed demands in early spring. Cool-season production of winter-active lucerne cultivars can be double that of winter-dormant lucernes, but their spring production is reduced because of depleted root reserves (White \& Lucas 1991).

Another technique for increasing production during the cool season is to include a winter-active grass with summer-active lucerne. A number of grass species, including prairie grass (Bromus willdenowii Kunth.) and phalaris (Phalaris aquatica L.), are winter active and would appear to complement the productivity curve of lucerne- (O'Connor 1967; Fraser 1982).

These combinations should theoretically be high yielding year round, but most mixtures studied appear to be unstable under the management regimes used, and either the grass or lucerne becomes dominant. The instability of lucerne-grass mixtures is probably due to interspecific competition for water, light, or nutrients. Responses to these factors can be influenced by irrigation, grazing duration, and fertiliser use. This work specifically examined the water use of pure lucerne and two lucerne-grass mixtures.

\section{Materials and methods}

The trial was located on a Templeton fine sandy loam with a field capacity of approximately $250 \mathrm{~mm}$ per metre depth above shingle, MAF soil 'Quick Test' indicated moderate soil fertility with values of $\mathrm{pH}$ 3.9, Ca 5, Mg 20, K 12, P 16.

The trial was a randomised complete block with a factorial combination of 3 pasture types and 2 grazing durations (Xu 1989). Plots (0.04 ha) were sown 4-7 November 1986 with grasses drilled in an east-west direction at $15-\mathrm{cm}$ row spacings. Inoculated 
and pelleted WL320 lucerne seed was cross drilled at the same row spacing. Irrigation was applied in December 1988 (60 mm), February $(60 \mathrm{~mm})$ and March (30 mm) 1989.

This paper reports a water use study superimposed on the above experiment during the 1988-89 growing season. Mini-plots of $8 \mathrm{~m}^{2}$ were located within the main experimental plots. Both shallow and deep sites were located with soil augers, giving 6 treatments consisting of the 3 pasture types at 2 soil depths: lucerne, lucerne- 'Grasslands' Matua prairie grass and lucerne- 'Grasslands' Maru phalaris, at $<50 \mathrm{~cm}$ soil depth and $>80 \mathrm{~cm}$ soil depth. There were $8 \mathrm{mini}-$ plots each for lucerne and lucerne-phalaris, deep and shallow, but only 4 each for lucerne-prairie, deep and shallow. Mini-plots were sited on representative areas of main plots and one neutron probe access tube was placed in each. Access tubes were also placed in adjacent headland areas of pure phalaris. Grazing duration was not considered and this factor was pooled when data were analysed.

Soil water content was measured using a Troxler Neutron Moisture Meter model 3333 at depths below $20 \mathrm{~cm}$. Probe readings were transformed into volumetric water content (VWC) using the following equation determined from an on site calibration:

$$
\text { VWC }=-0.0495+0.61 \times \text { count ratio }
$$

Soil water content was measured volumetrically in the top $20 \mathrm{~cm}$. Water use (ET) was calculated for each period between measurements as follows:

$$
\mathrm{ET}=\mathrm{ASWC}-(\mathrm{I}+\mathbf{R})
$$

where SWC = soil water content, $\mathrm{I}=$ irrigation, $\mathrm{R}$ $=$ rainfall. Soil water extraction patterns were determined by an intensive series of measurements, on $29 / 9,8 / 10,22 / 10,30 / 10,8 / 11,1988$.

Finally, root mass was sampled in May 1989 from cores $5 \mathrm{~cm}$ in diameter taken in the deep plots only. Each core was divided into six $10 \mathrm{~cm}$ length sections below the top $20 \mathrm{~cm}$. Roots were then washed out, and grass and lucerne roots separated. Headlands and races where pure prairie grass, phalaris perennial ryegrass, lucerne-ryegrass and white clover-ryegrass were growing provided areas where additional core samples were taken for comparison with trial swards.

\section{Results}

The 1988-89 growing season was dry, with rainfall from June 1988 to March 1989 being only $270 \mathrm{~mm}$, less than half the long term mean of $568 \mathrm{~mm}$. Temperature, solar radiation receipts, mean vapour pressure deficit and potential evapotranspiration were all well above the long term means for this period.

\section{Yield}

Pure lucerne produced the highest yield and pasture on deep soils produced significantly more DM than that on shallow soils (Table 1). While the interaction was not statistically significant, lucerne-prairie yields tended to be less in shallow than in deep soil (8.5 vs $12.3 \mathrm{t} / \mathrm{ha}$ ).

Seasonal DM production was similar in ranking to total, with lucerne generally producing more DM than mixtures (Table 1). Even during winter, yields of pure lucerne and grass mixtures did not differ. The significant interaction in the September harvest occurred because luceme-phalaris produced $3.2 \mathrm{t}$ $\mathrm{DM} / \mathrm{ha}$ on the shallow soil and only 2.8 t/ha on the deep soil, while other pasture types were unaffected by soil depth.

Lucerne yield from pure lucerne was higher than from lucerne-phalaris and lucerne-prairie (Table 2). As with total yield, lucerne yield was lower in shallow soil. An important interaction showed that while depth did not affect lucerne yield in pure lucerne and

Table 2 Effects of pasture type and soil depth on lucerne and grass yields (t/ha).

\begin{tabular}{lcc}
\hline & Lucerne (n) & Grass (n) \\
\hline Pasture type & & \\
$\quad$ lucerne & $12.3(16)$ & - \\
lucerne-prairie & $6.5(8)$ & $3.9(8)$ \\
lucerne-phalaris & $9.9(16)$ & $1.5(16)$ \\
lsd $(\mathrm{P}=0.05)$ & 1.65 & 0.80 \\
Soil depth & & \\
$\quad$ shallow & $9.3(20)$ & $2.6(20)$ \\
deep & $11.1(20)$ & $2.0(20)$ \\
lsd $(\mathrm{P}=0.05)$ & 1.21 & 0.70 \\
Interactions (P) & 0.02 & 0.15 \\
cv $(\%)$ & 18.00 & 36.00 \\
\hline
\end{tabular}

Table 1 Effects of pasture type and soil depth on DM yield (t/ha).

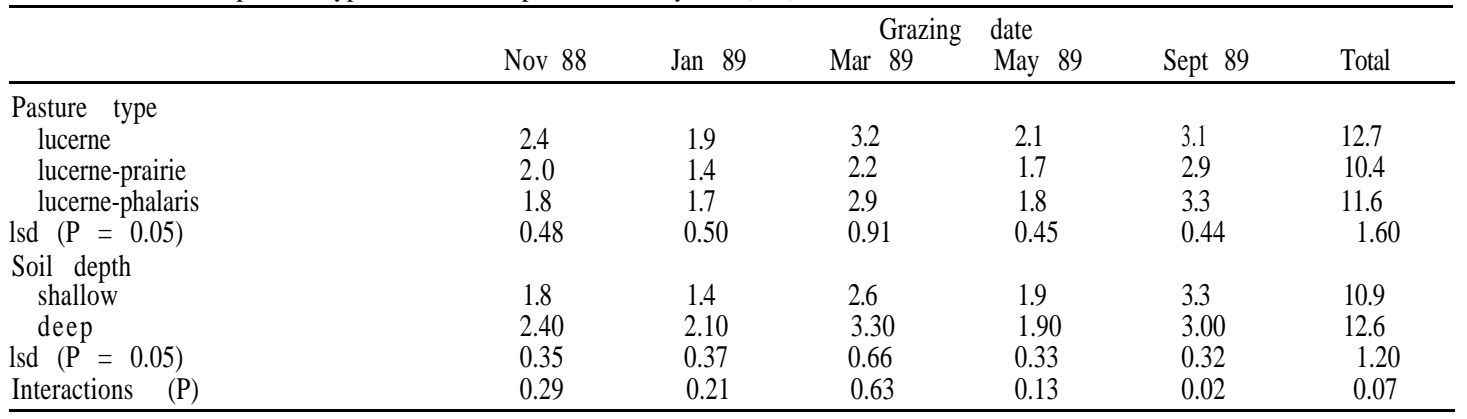


Table 3 Water use (ET) and water use efficiency (WUE) of three pasture types and two soil depths.

\begin{tabular}{lcc}
\hline & ET $(\mathrm{mm})$ & $\begin{array}{c}\text { Mean WUE } \\
\left(\mathrm{kg} \mathrm{DM} / \mathrm{ha} / \mathrm{mm} \mathrm{H}_{\mathbf{2}} \mathrm{O}\right)\end{array}$ \\
\hline Pasture type & & \\
$\quad$ lucerne & 384 & 25 \\
lucerne-prairie & $\mathbf{3 7 6}$ & 20 \\
lucerne-phalaris & 375 & 22 \\
lsd $(\mathrm{P}=0.05)$ & 25 & 3.1 \\
Soil depth & & \\
$\quad$ shallow & 360 & 21 \\
$\quad$ de ep & 398 & 24 \\
lsd (P = 0.05) & 18 & 3.0 \\
Interactions (P) & 0.61 & 0.21 \\
cv (\%) & 7 & 19 \\
\hline
\end{tabular}

lucerne-phalaris, only $4.0 \mathrm{t}$ of lucerne $\mathrm{DM} / \mathrm{ha}$ was produced in lucerne-prairie plots on shallow soil, less than half the $8.5 \mathrm{t}$ produced on deep soil. There was significantly more lucerne in lucerne-phalaris than lucerne-prairie plots.

Prairie grass produced more DM than phalaris (Table 2), in total and at each harvest. Soil depth had no effect on DM production for both species and at both soil depths was highest at the September harvest when 1190 and $700 \mathrm{~kg} / \mathrm{DM} / \mathrm{ha}$ was produced by prairie and phalaris, respectively.

Lucerne-grass mixtures significantly reduced weed yields: pure lucerne plots had $390 \mathrm{~kg}$ of weed DM/ha while lucerne-prairie and lucerne-phalaris had 10 and $100 \mathrm{~kg}$ weed $\mathrm{DM} / \mathrm{ha}$ respectively.

\section{Water use}

Water use did not differ between pasture types (Table 3). Over each period of growth, water use was approximately the same for each sward, but soil profile depth did affect ET. This trend was consistent during each growing period except for the period of $7 / 1 / 89-1 / 3 / 89$ when water use was approximately $142 \mathrm{~mm}$ for all three swards at both soil depths.

Pure lucerne had the highest mean water use efficiency (WUE) (Table 3). WUE of lucerne-prairie was lower than that for lucerne and lucerne-phalaris during the summer from $9 / 11 / 88$ until $2 / 3 / 89$. However, during the rest of the year, values of WUE were approximately the same for all three swards and ranged from 22 to $30 \mathrm{~kg} \mathrm{DM} / \mathrm{ha} / \mathrm{mm}$. Soil-depth had little effect on WUE except from $\mathbf{9} / 1 \mathbf{1} / 88$ to $6 / 1 / 89$, when the mean WUE of swards on deep soils $(24 \mathrm{~kg}$ $\mathrm{DM} / \mathrm{ha} / \mathrm{mm}$ ) was $26 \%$ higher than on shallow soils (19 $\mathrm{kg} \mathrm{DM} / \mathrm{ha} / \mathrm{mm})$.

\section{Water extraction patterns}

In shallow soils all pasture types extracted water from all depths between 1st and 2nd measurements, extraction declined between the 2nd and 3rd measurements when water content reached approximately 20 and $12 \mathrm{~mm} / 10 \mathrm{~cm}$ layer at the 20 and $30 \mathrm{~cm}$ depth (Figure 1). Under these conditions only pure lucerne and pure phalaris extracted water.
In deep soils, pure lucerne extracted water down to $100 \mathrm{~cm}$ between 1st and 2nd measurements, but there was little change after the 2nd measurement (Figure 2). Lucerne-prairie could extract water from 90-100 $\mathrm{cm}$ and extracted significant amounts between the 2nd and 3rd measurements at depths to $70 \mathrm{~cm}$. Phalaris and lucerne-phalaris extracted water to 70 and $90 \mathrm{~cm}$, respectively, but there was little change at depth after the 2nd measurement.

\section{Root yields}

In all pure swards most roots were found in the top $20 \mathrm{~cm}$ (Figure 3), but lucerne and phalaris had higher root yields at depth than did prairie grass and ryegrass. Root yields of mixtures were quite different to those of pure stands (Figure 4). In the lucerneprairie mixture lucerne root yields declined sharply in the top $20 \mathrm{~cm}$, compared with pure lucerne and there were few lucerne roots below $50 \mathrm{~cm}$. The lucerne root yield and distribution in the lucerne-phalaris mixture was similar to that in the pure lucerne stand, with significant amounts of root down to $80 \mathrm{~cm}$. The lucerne-phalaris mixture had $54 \%$ of its total root in the top $20 \mathrm{~cm}$, of which $88 \%$ was lucerne, while the lucerne-prairie mixture had $70 \%$ of total root yield in the top $20 \mathrm{~cm}$, only $60 \%$ of which was lucerne.

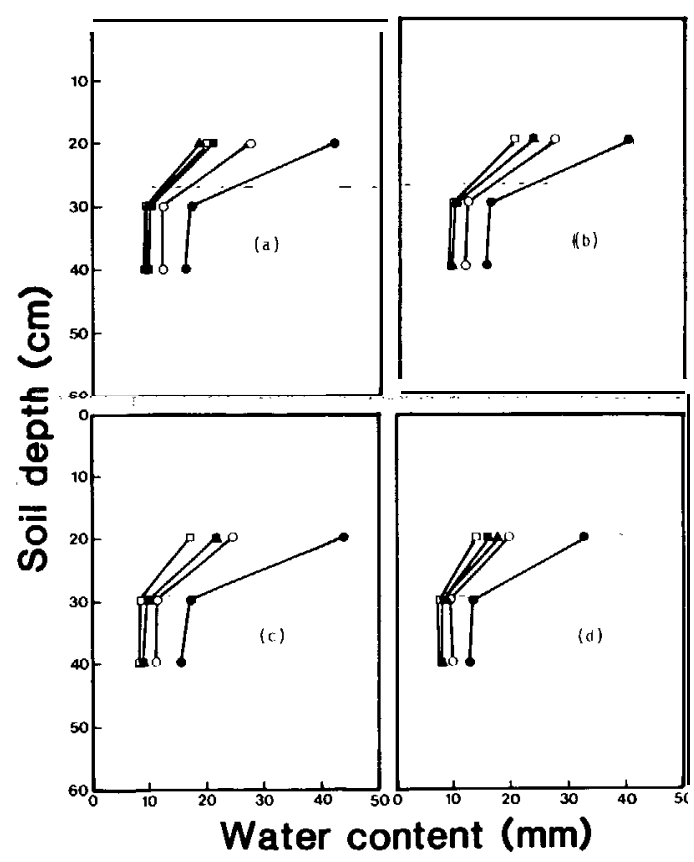

Figure 1 Changes in soil water content under lucerne (a), phalaris (b) lucerne-prairie (c) and lucerne-phalaris (d) swards in shallow soils during a drying cycle in spring 1988 . (๑) $29 / 9 / 88$, (O) $13 / 10 / 88$, (ए) $22 / 10 / 88$, () $29 / 10 / 88$, (A) $7 / 11 / 88$. 


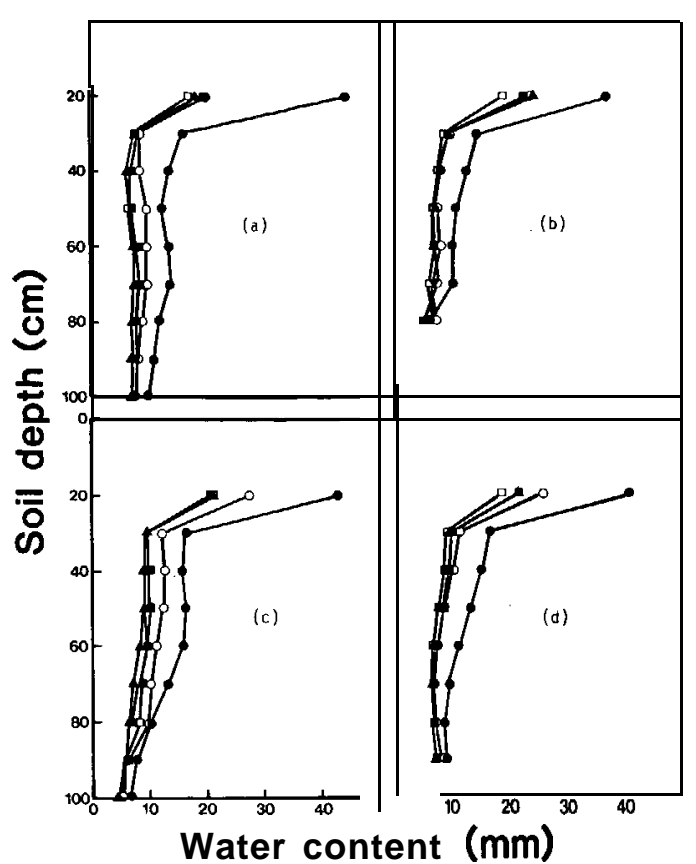

Figure 2 Changes in soil water content under lucerne (a), phlalaris (b) lucerne-prairie (c) and lucerne-phalaris (d) swards in deep soils during a drying cycle in spring 1988. (O) 29/9/88, (0) 13/10/88, (G) 22/10/88, (0) 29/10/88, (A) $7 / 11 / 88$.

\section{Discussion}

Adding the two grasses to lucerne clearly gave no yield advantage, as also shown by O'Connor (1967), Vartha (1973), Douglas \& Kinder (1973), Langer (1977) and Fraser (1982). The mixtures appeared to have a slight advantage on deep soil, where their yield was not significantly reduced and they reduced weed yields.

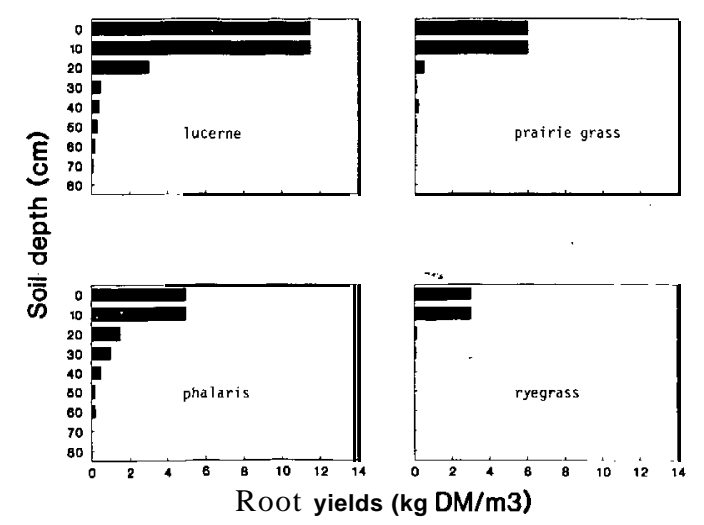

Figure 3 Root dry matter yields of lucerne, prairie grass, phalaris and perennial ryegrass at different depths down the soil profile.
The seasonal yields (Table 1) were not typical of lucerne-grass mixtures at Lincoln. Spring and summer yields were lower and winter yields were higher than those of other reports (O'Connor 1967; Vartha 1973; Fraser 1982), probably because of the unusually dry spring and summer followed by a moist warm winter.

The stability of these mixtures appeared to be affected by soil depth. On shallow soils prairie grass suppressed lucerne and gave a large total yield loss, while phalaris had little effect on the lucerne and total yields were equivalent to those of pure lucerne. On shallow soil, prairie grass accounted for 55\% of total yield compared with only $26 \%$ of total yield on deep soils where lucerne was dominant.

There are several reasons for prairie grass dominance on shallow soil. Prairie grass shading lucerne at the seedling stage reduced lucerne establishment (Xu 1989); the large mass of prairie grass roots in the soil surface layers may have reduced water availability to lucerne plants; and the shallow soils would have restricted water availability at depth.

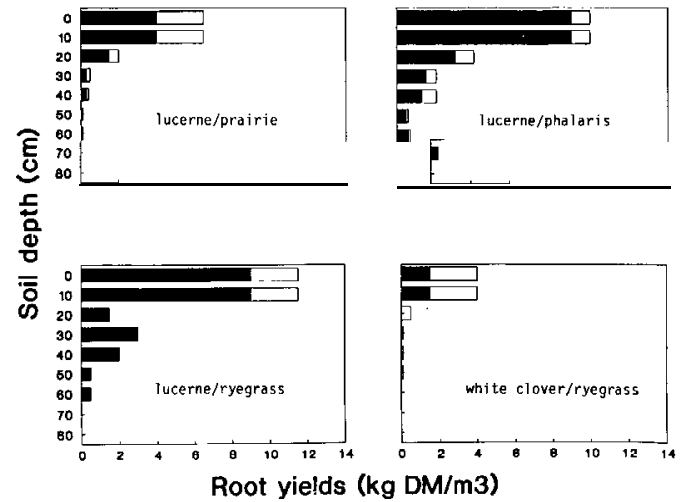

Figure 4 Root dry matter of lucerne-prairie, lucernephalaris, lucerne-ryegrass and white clover-ryegrass at

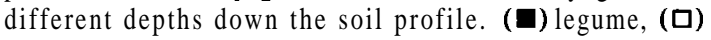
grass.

During the dry spring and summer, high soil moisture deficits may have eliminated any differences in water use between pasture types. Chamblee (1958) and Snaydon (1972) also reported no differences in water use between lucerne and other pastures.

The effect of soil depth on water use relates well to its effect on DM yields. During the dry spring and summer, the higher water use in deep soils was clearly due to more total water in the deeper profile; when moisture was not limiting (as in the autumn and winter) water use did not differ between depths.

The mean WUE of pure lucerne $(25 \mathrm{~kg}$ $\mathrm{DM} / \mathrm{ha} / \mathbf{m m}$, see Table 3) was higher than the mean value of $14.17 \mathrm{~kg} \mathrm{DM} / \mathrm{ha} / \mathrm{mm}$ reported in the US by 
Heichel (1983). Water stress often increases WUE because the yield loss is often accompanied by a greater proportional reduction of water loss (Rawson et al. 1977). The high WUE reported here also may be due to an underestimation of water used by lucerne. The root distribution indicated that lucerne roots were found right down to the underlying shingle layer. Water might have been extracted from the spaces between the particles of shingle as has been reported by Hayman \& Stocker (1982), but neutron access tubes could not be installed into the shingle layer.

The very low WLJE of lucerne-prairie on shallow soils $(10 \mathrm{~kg} \mathrm{DM} / \mathrm{ha} / \mathrm{mm})$ indicated that the interspecific competition for soil moisture in the top $20 \mathrm{~cm}$ reduced WUE. Root distributions showed the marked reduction in lucerne root mass in the top 20 $\mathrm{cm}$ when grown with prairie grass (Figure 4). Clearly the mixture is unsuitable for unirrigated shallow soils.

In shallow soils, significant water was extracted under all pastures until the water content reached about $15 \mathrm{~mm}$ at the $20 \mathrm{~cm}$ depth and below $10 \mathrm{~mm}$ at 30 and $40 \mathrm{~cm}$ depths (Figure 1). Since soil water content changed significantly at the $40 \mathrm{~cm}$ depth when soil moisture was not limiting, it can be assumed that all pastures (pure lucerne and pure phalaris, mixed lucerne-prairie grass and lucernephalaris) could extract water from below the depth of measurement, i.e. from the gravelly subsoil. This was demonstrated by Hayman \& Stocker (1982), who, when working with only four access tubes, found that on the stony Eyre soil, $32 \%$ of the deficit under pasture and $40 \%$ of the deficit under lucerne came from the gravel sub-strata. In deep soils, pure lucerne extracted significant--water up to the-maximum-depth measured of $1 \mathrm{~m}$, and it can thus be extrapolated that the further extraction occurred from below this depth. Pure phalaris, lucerne-prairie grass and lucerne-phalaris, extracted significant water only up to $70 \mathrm{~cm}$ depth (Figure 2), and at $80 \mathrm{~cm}$ depth soil water content did not change between the different measurement dates even when soil moisture was adequate in early spring. Thus it seems that inclusion of grasses at initial establishment reduces the ability of lucerne to extract water from deeper layers of the soil profile, which may partially explain the lower DM production of mixtures during -drought. This implies that in order to enable the lucerne to establish a deep root system, grasses should be overdrilled into well established lucerne rather than by mixing the species at initial sowings.

\section{Conclusions}

1. Aggressive grasses such as Matua prairie grass are unlikely to give any yield advantages over pure lucerne when sown in a mixture with lucerne on drought prone shallow soils.
Competition for water use from the dense grass root mass restricts lucerne root development which may result in reduced yields during dry periods.

2. Less aggressive grasses such as Maru phalaris will reduce lucerne yield when sown in mixtures with lucerne in summer-dry areas but total yield should be similar to pure lucerne and weed invasion will be reduced.

3. Overdrilling winter active grasses into mature lucerne may be the best way to establish productive lucerne-grass mixtures.

\section{REFERENCES}

Chamblee, D.S. 1958. The relative removal of soil moisture by alfalfa and orchard grass. Agronomy journal 50: 587-589.

Douglas, J.A.; Kinder, J.W. 1973. Production and composition of various lucerne-grass mixtures in a semi-arid environment. $N Z$ journal of experimental agriculture I: 23-27.

Fraser, T.J. 1982. Evaluation of 'Grasslands Matua' prairie grass and 'Grasslands Maru' phalaris with or without lucerne in Canterbury. $N Z$ journal of experimental agriculture 10: 235-237.

Hayman, J.M.; Stocker, R.V. 1982. Soil water extraction patterns under pasture and lucerne on two soil types in Canterbury. Proceedings of the Agronomy Society of $N$ ew Zealand 12: 61-63.

Heichel, G.H. 1983. Alfalfa. pp. 127-155. In Crop Water Relations. Teare, I.D. \& Peet, M.M. (eds). New York: John Wiley and Sons.

Langer, R.H.M. 1982. Lucerne. pp. 347-364. In Langer, R.H.M. (ed.) Pasture and Pasture Plants. Wellington: Reed.

O'Connor, K.F. 1967. Lucerne-grass associations under different sowing and defoliation systems. pp. 163-176. In Langer, R.H.M. (ed.). The Lucerne Crop. Wellington: Reed.

Rawson, H.M.; Begg, J.E.; Woodward, R.G. 1977. The effect of atmospheric humidity on photosynthesis, transpiration and water use efficiency of leaves of several plant species. Planta 134: S-10.

Snaydon, R.W. 1972. Soil water contents beneath summeractive swards in a seasonally semi-arid environment Agricultural meteorology 10:349-363.

Vartha, E.W. 1973. Performance of lucerne-grass mixtures on Wakanui silt loam. NZ journal of experimental agriculture I: 29-34.

White, J.G.H.; Lucas, W.J. 1991. Management of lucerne in the cool season. Proceedings of the $\mathrm{NZ} G$ rassland Association 52: In press.

$\mathrm{Xu}, \mathrm{H}$. 1989. Grazing duration studies on lucerne-grass mixtures. MAgrSc Thesis. Lincoln College, Canterbury University. 